\title{
Effects of autoclaving on the apparent digestibility coefficient of dehulled pea seed meal (Pisum sativum L.) in rainbow trout (Oncorhynchus mykiss W.)
}

\author{
Adrián Hernández ${ }^{1,2}$, Aliro Bórquez ${ }^{1,2}$, Leonardo Alcaíno ${ }^{1,2}$, Jorge Morales, \\ Patricio Dantagnan ${ }^{1,2}$ and $^{1}$ Patricio Saez ${ }^{1,2,3}$ \\ ${ }^{1}$ Escuela de Acuicultura, Universidad Católica de Temuco. Casilla 15-D, Temuco, Chile. \\ ${ }^{2}$ Unidad de Nutrición Acuícola, Centro de Genómica Nutricional Agro-acuícola. Casilla 58-D, Temuco, Chile. \\ ${ }^{3}$ UG/OMNR Fish Nutrition Research Lab, Department of Animal and Poultry Science, University of \\ Guelph, Guelph, Ontario, Canada N1G 2W1.
}

\begin{abstract}
A. Hernández, A. Bórquez, L. Alcaíno, J. Morales, P. Dantagnan, and P. Saez. 2010. Effects of autoclaving on the apparent digestibility coefficient of dehulled pea seed meal (Pisum sativum) in Rainbow trout (Oncorhynchus mykiss). Cien. Inv. Agr. 37(3): 39-46. The effect of autoclaving on the nutrients' apparent digestibility coefficient (ADC), digestible protein and energy of pea seed meal (P. sativum) fed to Rainbow trout (O. mykiss) was examined. Two samples of the pea meal were autoclaved at $121^{\circ} \mathrm{C}$ and $1.1 \mathrm{~atm}$ for $5 \mathrm{~min}\left(5^{\prime} \mathrm{APM}\right)$ or $15 \mathrm{~min}$ (15'APM), respectively. A third sample, used as control, was not treated (RPM). One reference diet (Basal diet) and 3 experimental diets were elaborated and labelled based on autoclaving time applied to the ingredient (RPM, 5' APM and 15' APM). The four diets were assigned using a completely randomised design, with each treatment having three replicates. 12 tanks were stocked each with 15 trouts with an average weight of $235 \pm 10.4 \mathrm{~g}$. Faeces were collected over a 7-day period using a settlement column and pooled within the tank. ADCs were determined using chromium oxide $\left(\mathrm{Cr}_{2} \mathrm{O}_{3}\right)$ as an inert digestibility indicator. No significant differences $(\mathrm{P}>0.05)$ regarding protein $\mathrm{ADC}$ were found among all treatments. On the other hand, dry matter, energy and nitrogen free extract (NFE) ADC showed significant differences $(p<0.05)$ among all the different treatments. Results showed that 5'APM improved dry matter, protein, and energy ADC of the dehulled pea seed meal in diets for rainbow trout.
\end{abstract}

Key words: Autoclaving, apparent digestibility coefficient, pea seed meal, rainbow trout.

\section{Introduction}

Feeding plays a key role in any intensive aquaculture operation. Fishmeal has been used as the main protein source in salmonid feeds be-

Received July 10, 2009. Accepted January 21, 2010. Corresponding author: ajhernandez@uct.cl cause of its high nutritional quality; however, it is also one of the most expensive ingredients (Wang et al., 2008).

The nutritional value of an ingredient or diet depends on its chemical composition, but also on how much of its nutrients the fish can absorb and utilize (NRC, 1993). Based on that, the need for reliable methods to study the ingredient and diet 
utilization has resulted in the development of several methodologies to estimate the amount of nutrients that are absorbed and available to the fish (Vandenberg and De la Noüe, 2001). In this regard, Allan et al. (2000), claimed that nutrient digestibility determination is the first step in evaluating the potential use of an ingredient in diets for reared species.

Legume seeds appear to be an acceptable source of protein for animal feed formulation, due to their relatively low cost and long conservation time (Trugo et al., 2000). Among legumes, pea seed (Pisum sativum L) has become widely available as a low cost protein source for animal feed. However, despite the nutritional potential of peas as an inexpensive and rich source of proteins, carbohydrates, vitamins and some minerals, the utilization of this legume has been limited by its low protein digestibility, essential amino acid deficiency and the presence of certain anti-nutritional factors. Among these are: phytic acid, condensed tannins, polyphenols, protease inhibitors (trypsin and chymotrypsin), $\alpha$-amylase inhibitors and lectins, which reduce the nutritional quality of the protein (Alonso et al., 1998).

Several industrial or home scale processes, such as soaking, germination, dehulling, milling, cooking, roasting or fermentation have been used to improve the nutritional properties of legumes. However, the efficacy of these treatments has been found to be variable (Alonso et al., 2000).

Several studies have been carried out in order to demonstrate the potential of peas and related feedstuffs in formulated diets for fish. Gomes et al. (1993) showed that colzapro, a co-extruded product of rapeseed (Brassica napus L.) meal and pea seed, can be utilized in rainbow trout (Oncorhynchus mykiss W.) diets at levels up to $20 \%$ without negative effects on growth, nitrogen or energy utilization and muscle fatty acid composition. Gouveia and Davis (2000), after an 11-week feeding trial, observed a positive but nonsignificant trend for both growth and feed uti- lization with increasing incorporation of pea seed meal in diets for juvenile European sea bass (Dicentrarchus labrax L.).

The aim of this trial was to determine whether different periods (5 and 15 minutes) of heat/ pressure treatment (autoclave) may have an effect on the nutrient apparent digestibility coefficient (ADC) and digestible protein and energy of dehulled pea seed meal in pelletized diets for rainbow trout.

\section{Material and methods}

\section{Ingredients}

Pea beans (P. sativum cv. Nitouche) were kindly donated by the INIA Carillanca, Chile; the sample was dehulled and ground to $<300 \mu \mathrm{m}$ particle size. Afterwards, two samples of the pea meal were autoclaved at $121^{\circ} \mathrm{C}$ and $1.1 \mathrm{~atm}$ for 5 or $15 \mathrm{~min}$; these were labelled 5-min autoclaved pea meal (5'APM) and 15-min autoclaved pea meal (15'APM), respectively. These samples were oven-dried at $50{ }^{\circ} \mathrm{C}$ for approximately 15 hrs. A third not-treated sample was used as control and labelled as raw pea meal (RPM). The nutritional composition of the ingredient is presented in Table 1.

\section{Diets}

The ingredients of the basal diet were thoroughly mixed and used for further elaboration of all experimental diets. The ingredient of study for each test diet was added to a sub-sample of the basal diet in a proportion of 30:70, respectively. Diets were processed by addition of water (about $25 \%$ of mash dry weight) while mixing to form dough, which were subsequently screw pressed using a $3.5 \mathrm{~mm}$ diameter die. The resultant moist pellets were oven-dried at $60{ }^{\circ} \mathrm{C}$ for approximately $15 \mathrm{H}$. The basal diet was prepared in a similar manner. Formulation and chemical composition of the experimental diets are presented in Table 2. 
Table 1. Nutrient composition of the experimental ingredients ${ }^{1}$.

\begin{tabular}{lrrr}
\hline & RPM & 5'APM & 15'APM \\
\hline Dry Matter & 89.85 & 91.37 & 91.17 \\
Protein & 24.93 & 25.80 & 25.14 \\
Fat & 1.09 & 1.74 & 1.24 \\
Nitrogen free extract & 69.69 & 68.41 & 69.82 \\
Fiber & 1.42 & 1.30 & 1.08 \\
Ash & 2.88 & 2.75 & 2.73 \\
Gross energy (MJ $\cdot \mathrm{kg}^{-1}$ Dry matter) & 16.68 & 16.90 & 16.67 \\
\hline
\end{tabular}

${ }^{1} \mathrm{~g} \cdot \mathrm{kg}^{-1}$ dry matter, unless otherwise indicated.

Table 2. Formulation and chemical composition of the experimental diets ${ }^{1}$.

\begin{tabular}{|c|c|c|c|c|}
\hline Ingredient & Basal diet & RPM & 5'APM & 15'APM \\
\hline Fish meal $^{2}$ & 65 & 45.5 & 45.5 & 45.5 \\
\hline Fish oil ${ }^{3}$ & 11 & 7.7 & 7.7 & 7.7 \\
\hline Raw pea meal ${ }^{4}$ & 0 & 30 & 0 & 0 \\
\hline $5^{\prime}$ autoclaved pea meal ${ }^{5}$ & 0 & 0 & 30 & 0 \\
\hline $15^{\prime}$ autoclaved pea meal ${ }^{6}$ & 0 & 0 & 0 & 30 \\
\hline Pregelatinized starch ${ }^{7}$ & 15 & 10.5 & 10.5 & 10.5 \\
\hline Cellulose $^{8}$ & 6.5 & 4.6 & 4.6 & 4.6 \\
\hline Vitamin premix ${ }^{9}$ & 0.5 & 0.4 & 0.4 & 0.4 \\
\hline Mineral premix ${ }^{10}$ & 0.5 & 0.4 & 0.4 & 0.4 \\
\hline Chromium oxide $^{11}$ & 1.5 & 1.1 & 1.1 & 1.1 \\
\hline \multicolumn{5}{|l|}{ Diet Nutrient Content } \\
\hline Dry matter & 93.48 & 93.04 & 92.95 & 93.16 \\
\hline Protein & 46.82 & 40.25 & 40.29 & 39.68 \\
\hline Lipids & 18.09 & 11.59 & 12.53 & 12.6 \\
\hline Nitrogen free extract & 18.57 & 33.87 & 32.42 & 33.72 \\
\hline Fiber & 4.24 & 4.91 & 5.04 & 4.69 \\
\hline Ash & 12.28 & 9.38 & 9.73 & 9.31 \\
\hline Chromix oxide & 1.67 & 1.24 & 1.23 & 1.20 \\
\hline Gross energy $\left(\mathrm{Mj} \cdot \mathrm{kg}^{-1}\right)$ & 20.51 & 19.39 & 19.53 & 19.46 \\
\hline
\end{tabular}

${ }^{1} \mathrm{~g} \cdot \mathrm{kg}^{-1}$ dry matter, unless otherwise indicated.

${ }^{2}$ Supplied by Pesquera San Jos S.A., Chilean jurel meal super prime (Prot. 68\%, Fat $9.9 \%$, Ash $14.5 \%$ ).

${ }^{3}$ Supplied by BioMar Chile S.A., Puerto Montt, Chile.

4,5, 6 Produced from pea bean and processed as described in material and methods Section.

${ }^{7}$ Supplied by Mathiesen SAC, Santiago, Chile.

${ }^{8}$ Supplied by Sigma - Aldrich $\alpha$-cellulose (Fibers).

${ }^{9}$ Vitamins includes (IU/kg or g/ kg of premix): Vitamin A $1.0 \mathrm{MIU}$; Vitamin D3, 0.5 MIU; Vitamin E, 0.04 MIU; Vitamin K3, 4 g; Vitamin B1, 4 g; Vitamin B2, 6 g; Vitamin B5, 10 g; Vitamin B6, 2 g; Vitamin B9, 1.6 g; Vitamin B12, 0.00 4g; Niacin, 40 g; Biotin, 0.1 g; Vitamin C 100 g; Choline, $200 \mathrm{~g}$; Inositol $50 \mathrm{~g}$.

${ }^{10}$ Minerals includes (g/kg of premix): Manganese, $50 \mathrm{~g}$; Zinc, $100 \mathrm{~g}$; Copper, $2 \mathrm{~g}$; Ferrous iron, $35 \mathrm{~g}$; Selenium, $0.1 \mathrm{~g}$; Iodine, $4 \mathrm{~g}$; Cobalt, $0.4 \mathrm{~g}$.

${ }^{11}$ Supplied by Sigma - Aldrich Chromiun (III) oxide. 


\section{Fish handling}

Hatchery-reared, same cohort rainbow trouts (O. mykiss) were transferred from the Experimental Station Los Laureles (IX region, Chile) to cylinder-conical tanks $(500 \mathrm{~L})$ at the Escuela de Acuicultura, Universidad Católica de Temuco, Temuco, Chile. Freshwater $\left(14.6 \pm 0.1{ }^{\circ} \mathrm{C}\right)$ was supplied to each of the tanks at a change rate of $1.0 \cdot \mathrm{H}^{-1}$. Twelve tanks were stocked each with 15 trouts with an average weight of $235.1 \pm$ $10.4 \mathrm{~g}$. Fish were acclimatized to the tanks and to each dietary treatment during 10 days before initiating the faecal collection (Glencross et al., 2003). Fish were fed manually twice a day, and faeces were collected using a settlement column faecal collector as described by Bureau and Cho (1999). Faeces were collected over a period of 7 days. During this time, samples were pooled within the tank and kept at $-80{ }^{\circ} \mathrm{C}$ before being freeze-dried for 48 hours in preparation for analysis.

\section{Chemical and digestibility analysis}

Diets and faecal samples were analysed for dry matter, chromium oxide, ash, fibre, fat, nitrogen and gross energy content. Dry matter was calculated by gravimetric analysis following ovendrying at $105{ }^{\circ} \mathrm{C}$ for 24 hours. Chromic oxide levels were determined spectrophotometrically following the digestion and oxidation of samples using a modified Furukawa and Tsukahara (1966) technique. Protein levels were calculated from the determination of total nitrogen by Kjeldhal digestion, based on $N^{*} 6.25$. Total lipid content was determined gravimetrically following extraction of the lipids with solvent (Soxhlet). Ash content was determined gravimetrically following loss of mass after combustion of a sample in a muffle furnace at $550{ }^{\circ} \mathrm{C}$ for 3 hours. Fibre content was calculated by gravimetric analysis following oven-drying at $105^{\circ} \mathrm{C}$ for 24 hours, after acid and alkali digestion with Sulphuric acid and Sodium hydroxide respectively. Nitrogen free extract (NFE) content was determined by the difference approach. Gross energy content was determined by adiabatic bomb calorimeter using benzoic acid as the standard. All of these determinations were con- ducted according to the methods specified by the AOAC (Association of Official Analytical Chemists) (1995), unless otherwise indicated. Diet apparent digestibility coefficients $\left(\mathrm{ADC}_{\text {Diet }}\right)$ were calculated using the formula:

$$
A D C_{\text {Diet }}=100-\left(100 \times \frac{\text { Nutrient }_{\text {Faeces }}}{\text { Nutrient }_{\text {Diet }}} \times \frac{\mathrm{Cr}_{2} \mathrm{O}_{3 \text { Diet }}}{\mathrm{Cr}_{2} \mathrm{O}_{3 \text { Faeces }}}\right)
$$

$\mathrm{Cr}_{2} \mathrm{O}_{3 \text { Diet }}$ and $\mathrm{Cr}_{2} \mathrm{O}_{3 \text { Faeces }}$ represent the chromium oxide content of the diet and faeces, respectively. Nutrient $t_{\text {Diet }}$ and Nutrient $t_{\text {faeces }}$ represent the nutritional variables of concern (dry matter, protein or energy) contained in the diet and faeces, respectively (Glencross et al., 2003). The digestibility values of the test ingredients examined in this study were calculated according to the formula:

$A D C_{\text {Ingredient }}=\left(\frac{A D C_{\text {Test }} \times \text { Nutrient }_{\text {Test }}-\left(A D C_{\text {Basal }} \times \text { Nutrient }_{\text {Basal }} \times 0.7\right)}{\left(0.3 \times \text { Nutrient }_{\text {Ingredient }}\right)}\right)$

Where $\mathrm{ADC}_{\text {Ingredient }}$ is the digestibility of the test ingredient included in the test diet at 30\%. $\mathrm{ADC}_{\text {test }}$ is the apparent digestibility of the test diet. $\mathrm{ADC}_{\text {basal }}$ is the apparent digestibility of the basal diet, which represents $70 \%$ of the test diet (Cho and Kaushik, 1990).

Digestible protein and energy of the diets were calculated by multiplying the apparent protein and energy digestibility coefficients (CDA) by the protein and energy content determined for each ingredient respectively.

\section{Design and Statistical analysis}

Treatments were assigned to the experimental array on a completely randomised design, with each treatment having three replicates. All were mean values unless otherwise specified. Data were analysed for homogeneity using Levene's test. Effects of ingredient on digestibility of dry matter, protein, energy and NFE in each of the ingredient were examined by one-way ANOVA. Levels of significance were determined using the Tuckey's test. Percentage values for ADC were normalized by the arcosine transformation according to Sokal and Rohlf (1969). Limits for all critical ranges 
were set at $\mathrm{P}<0.05$. All statistical analyses were carried out using the SPSS Version 11.5 (SPSS Inc, Chicago, USA, 2009).

\section{Results}

Nutrients' ADC and digestible protein and energy values are presented in Table 3 . There were not significant differences $(\mathrm{P}>0.05)$ regarding protein $\mathrm{ADC}$ among treatments. On the other hand, dry matter, energy and NFE ADCs showed significant differences $(\mathrm{P}<0.05)$. Dry matter ADC was significantly higher $(\mathrm{P}<0.05)$ for the 5'APM and 15'APM treatments with values of 59.29 and $57.92 \%$ respectively. Regarding energy, the ADC for 5'APM treatment had the highest $(\mathrm{P}<0.05)$ value $(68.58 \%)$; on the other hand, RPM (46.59\%) was significantly lower $(\mathrm{P}<0.05)$ than 15 'APM $(62.41 \%)$. The ADC for NFE showed a significant $(\mathrm{P}<0.05)$ increment when the autoclave treatment was applied, although there were no differences $(\mathrm{P}>0.05)$ as the heat/pressure exposure time was increased, with values of 37.71 and $42.74 \%$ for 5'APM and 15'APM respectively.

In the same way, results for digestible energy and protein were significantly different $(\mathrm{P}<0.05)$ after the heat/pressure treatment. Digestible protein was significantly higher $(\mathrm{P}<0.05)$ for 5'APM with a value of $223.78 \mathrm{~g} \cdot \mathrm{kg}^{-1}$ ingredient, compared with 203.78 and 207.98 for RPM and 15 'APM, respectively.

Finally, for digestible energy, 5'APM reached the highest value of $11.59 \mathrm{MJ} \cdot \mathrm{kg}^{-1}$, then $15^{\prime} \mathrm{APM}$ was significantly $(\mathrm{P}<0.05)$ lower with a value of $10.40 \mathrm{MJ} \cdot \mathrm{kg}^{-1}$, but higher than RPM, which had a value of $7.77 \mathrm{MJ} \cdot \mathrm{kg}^{-1}$.

\section{Discussion}

There are several nutritional factors affecting the decision to include plant protein into salmonid diets, and pea seed meal is not the exception. Although it is a rich source of protein, carbohydrates, fibre, vitamins and minerals (Vidal-Valverde et al., 2003), it has been reported that pea seed contains some anti-nutritional components that reduce its nutritive value for salmonid species. These factors include trypsin inhibitors, lectins (phytohaemagglutinins), gallic acid, tannins, cyanogens, phytic acid, saponins, antivitamins and other phenolic acids and substances with phytestrogenic effects (Francis et al., 2001; Dvorak et al., 2005). Most of them are thermo labile compounds, and heat treatments have been proved to be an effective way to reduce or eliminate some of these antinutritional factors and increase the nutritional value of this ingredient in diets for different species (Conan and Carre, 1989; Periago et al., 1996; Farhoomand and Poure, 2006; Stein and Bohlke, 2007).

It is recognized that heat processing is an effective method for inactivating trypsin inhibitors in soybeans (Stein and Bohlke, 2007). Heat treatment may also induce conformational changes in the pea proteins, which may make them more accessible to digestive enzymes and thus increase amino acids digestibility. In this

Table 3. Apparent digestibility coefficient and digestible protein and energy for the ingredient under different treatments

\begin{tabular}{|c|c|c|c|}
\hline $\mathrm{ADC}$ & RPM & 5'APM & $15^{\prime} \mathrm{APM}$ \\
\hline Dry Matter & $47.33 \pm 2.22^{\mathrm{a}}$ & $59.29 \pm 3.97^{b}$ & $57.92 \pm 3.37^{b}$ \\
\hline Protein & $81.74 \pm 3.29^{\mathrm{a}}$ & $86.72 \pm 1.67^{\mathrm{a}}$ & $82.74 \pm 2.99^{\mathrm{a}}$ \\
\hline Energy & $46.59 \pm 1.65^{\mathrm{a}}$ & $68.58 \pm 1.28^{\mathrm{b}}$ & $62.41 \pm 2.32^{\mathrm{c}}$ \\
\hline Nitrogen free extract & $32.04 \pm 0.25^{\mathrm{a}}$ & $37.71 \pm 6.82^{\mathrm{ab}}$ & $42.74 \pm 0.89^{b}$ \\
\hline \multicolumn{4}{|l|}{ Digestible protein and energy } \\
\hline Digestible Protein $\left(\mathrm{g} \cdot \mathrm{kg}^{-1}\right.$ ingredient $)$ & $203.78 \pm 8.19^{\mathrm{a}}$ & $223.78 \pm 4.30^{\mathrm{b}}$ & $207.98 \pm 5.31^{\mathrm{a}}$ \\
\hline Digestible Energy $\left(\mathrm{Mj} \cdot \mathrm{kg}^{-1}\right)$ & $7.77 \pm 0.28^{\mathrm{a}}$ & $11.59 \pm 0.22^{b}$ & $10.40 \pm 0.27^{\circ}$ \\
\hline
\end{tabular}

Values are mean \pm Standard deviation $(\mathrm{n}=3)$.

$\mathrm{a}, \mathrm{b}, \mathrm{c}$ different superscripts among rows denote significant differences at $\mathrm{P}<0.05$. 
work, although there were not significant differences in protein ADC among the treatments, there was a trend to increase this value with the 5'APM treatment and then to decrease for the 15'APM treatment. In this regard, Alonso et al. (2000) claimed that thermal processing may also impair the quality and availability of some nutrients depending on the technology and conditions used; some amino acids can become unavailable after thermal treatment. This is due to the formation of cross-links or to Maillard condensation with reducing carbohydrates. Arndt et al. (1999) reported this kind of effect in soybean meal after extended heating. Nevertheless, the digestible protein results (Table $3)$ showed a significantly higher $(\mathrm{P}<0.05)$ value after the 5'APM treatment, meaning that there is a higher level of protein being digested $\left(\mathrm{g} \cdot \mathrm{kg}^{-1}\right.$ ingredient). This is very interesting taking into account that all pea meal (raw and autoclaved) had the same protein content (Table 1), suggesting a better protein utilization for fish growth, which may be subject of further research on this technological pre-process.

Another important concern regarding inclusion of vegetable protein sources into carnivorous animal diets is related to their content of nonstarch-polysaccharides (NSP). The alfa-galactoside linkages of these polysaccharides are not broken down by digestion in the gut of monogastric animals (Diaz et al., 2006). The pea seed meal used in this trial presented a NFE values ranging from 68.41 to $69.82 \%$ on a dry matter basis; starch is a main component of pea seed, and dehulled pea seeds contain approximately $52 \%$ starch on a dry matter basis (Cousing, 1997). So basically, improving digestibility of NFE depends on how the heat/pressure treatment affects the starch components, because even though starch is not an anti-nutritional factor, it is poorly digested and nutrient utilization can be affected by high starch levels in carnivorous fish diets (Thiessen et al., 2003). NFE apparent digestibility in this experiment was significantly $(\mathrm{P}<0.05)$ enhanced by autoclaving treatment in both 5'APM and 15'APM. These results indicate that autoclaving of pea meal improves the access of digestive enzymes to the starch molecule. In this respect, Periago et al. (1996) stated that starch digestibility could be affected by many other factors, such as starch granule structure and amylase/amylopectin proportion. In that sense, the main advantage of heating treatment on peas is the matrix structure change and starch granular disruption via gelatinization (Stein and Bohlke, 2007). On the other hand, pea starch contains up to $34 \%$ amylose, which is known to have a greater digestibility improvement with heat treatment (Thiessen et al., 2003).

Regarding digestible energy content of the ingredients, it was significantly $(\mathrm{P}<0.05)$ improved by treatments, being 5'APM the ingredient with the highest value for this parameter. The use of autoclaving, as with other processes such as extrusion, have shown to be important in increasing the nutrient availability of plant meals, especially in incresing the amount of digestible energy available through greater starch gelatinization (Borlongan, 2003). This factor might be of significant importance if we take into account that peas, compared to soy bean or canola, comprise the energy fraction as starch instead of oil (Thiessen et al., 2003).

Results of this work demonstrated that $5 \mathrm{~min}$ at $1.1 \mathrm{~atm}$ autoclaving treatment significantly enhances on dry matter, energy and NFE ADC. Furthermore, significantly higher $(p<0.05)$ values for total digestible energy and protein of the diet may make this pre-treated ingredient a new alternative for the formulation of cost-effective diets for salmonids; however, further research on growth trials are needed to assess the actual nutritive value of autoclaved pea seed meal for fish.

\section{Acknowledgements}

This study was supported by the "Dirección General de Investigación de la Universidad Católica de Temuco" Project DGIUCT 200703-16. 


\title{
Resumen
}

\begin{abstract}
A. Hernández, A. Bórquez, L. Alcaíno, J. Morales, P. Dantagnan y P. Saez. 2010. Efectos del autoclave sobre el coeficiente de digestibilidad aparente de la harina descascarada de arveja (Pisum sativum) en trucha arco iris (Oncorhynchus mykiss). Cien. Inv. Agr. 37(3):39-46. Se evalúo el efecto del tratamiento de autoclave de la harina de arveja (P. sativum) sobre los Coeficientes de Digestibilidad Aparente (CDA) de nutrientes, para trucha arco iris (O. mykiss). Dos muestras de harina de arveja fueron autoclavadas a $121{ }^{\circ} \mathrm{C}$ y $1,1 \mathrm{~atm}$ por 5 $\min \left(5^{\prime} \mathrm{APM}\right)$ y 15 min (15' APM) respectivamente; una tercera muestra, usada como control, no fue tratada (RPM). Las dietas fueron elaboradas y etiquetadas de acuerdo al tratamiento aplicado al ingrediente. Los tratamientos fueron aplicados en un diseño completamente aleatorio, y cada tratamiento se aplicó en triplicado. 15 peces con un peso promedio de 235 $\pm 10,4 \mathrm{~g}$ fueron transferidos a tanques cilindro-cónicos (500 L) con flujo de agua dulce. Las heces fueron colectadas usando una columna de decantación en cada tanque por un periodo de 7 días. Los CDAs fueron determinados usando oxido de cromo $\left(\mathrm{Cr}_{2} \mathrm{O}_{3}\right)$ como indicador inerte de digestibilidad. No hubo diferencias significativas $(\mathrm{P}>0,05)$ con respecto a los CDAs de proteína entre los tratamientos. Por otra parte, los CDAs de materia seca, energía y extracto no nitrogenado $(E N N)$ fueron estadísticamente diferentes $(P<0,05)$. Los resultados demostraron que el tratamiento 5'APM incrementó el CDA de materia seca, además de energía y proteína digestible de la harina descascarada de arveja.
\end{abstract}

Palabras clave: Autoclave, coeficiente de digestibilidad aparente, harina de arveja, trucha arco iris.

\section{References}

Allan, G. L., S. Parkinson, M. A. Booth, D. A. J. Stone, S. J. Rowland, J. Frances, and R. WarnerSmith. 2000. Replacement of fish meal in diets for Australian silver perch, Bidyanus bidyanus: I. Digestibility of alternative ingredients. Aquaculture 186:293-310.

Alonso, R., G. Grant, P. Dewey, and F. Marzo. 2000. Nutritional Assessment in Vitro and in Vivo of Raw and Extruded Peas (Pisum sativum L.). J. Agric. Food Chem. 48:2286-2290.

Alonso, R., E. Orúe, and F. Marzo. 1998. Effects of extrusion and conventional processing methods on protein and antinutritional factor contents in pea seeds. Food Chemistry 63:505-512.

Alonso, R., E. Orúe, M. Zabalza, J, G. Grant, and F. Marzo. 2000. Effect of extrusion cooking on structure and functional properties of pea and kidney bean proteins. J. Sci. Food Agric. 80:397-403.

AOAC. 1995. Methods of Analysis of the Association of Analytical Chemist. 16 $6^{\text {th }}$ Edition. AOAC, Washington, DC.

Arndt, R., R. Hardy, S. Sugiura, and F. Ong. 1999. Effects of heat treatment and substitution level on palatability and nutritional value of soy defatted flour in feeds for Coho Salmon, Oncorhynchus kisutch. Aquaculture 180:129-145.

Bautista-Teruel, M. N., P. S. Eusebio, and T. P. Welsh. 2003. Utilization of feed pea, Pisum sativum, meal as a protein source in practical diets for juvenile tiger shrimp, Penaeus monodon. Aquaculture 225:121-131.

Borlongan, I. G., P. S. Eusebio, and T. Welsh. 2003. Potential of feed pea (Pisum sativum) meal as a protein source in practical diets for milkfish (Chanos chanos Forsskal). Aquaculture 225:8998.

Bureau, D. P., and C. Y. Cho. 1999. Measuring digestibility in fish. UG/OMNR Fish Nutrition Research Laboratory. Technical document, University of Guelph, Ontario, Canada. 9 pp.

Cha, J. Y., R. A. Flores, and H. Park. 2000. Reduction of Carotenoids in Corn Gluten Meal with Soy Flour. Transcription of the ASAE 43:1169-1174.

Cho, C. Y. K., S.J. 1990. Nutritional energetics in fish: energy and protein utilisation in rainbow trout (Salmo gairdnerii). World Rev. Nutr. Diet. 61:132-172.

Conan, L., and B. Carre. 1989. Effect of autoclaving on metabolizable energy value of smooth pea 
seed (Pisum sativum) in growing chicks. Animal Feed Science and Technology 26:337-345.

Cousing, R. 1997. (Pisum sativum L.). Field Crops Research 53:111-130.

Diaz, D., M. Morlacchini, F. Masoero, M. Moschini, G. Fusconi, and G. Piva. 2006. Pea seeds (Pisum sativum), faba beans (Vicia faba var. minor) and lupin seeds (Lupinus albus var. multitalia) as protein sources in broiler diets: effect of extrusion on growth performance. Ital. J. Anim. Sci. 5:43-53.

Dvořák, R., A. Pechová, L. Pavlata, J. Filípek, J. Dostálová, Z. Réblová, B. Klejdus, K. Kovařčík, and J. Poul. 2005. Reduction in the content of antinutritional substances in pea seeds (Pisum sativum L.) by different treatments. Czech J. Anim. Sci. 50:519-527.

Farhoomand, P., and S. S. Poure. 2006. Study on the nutritional value of raw, dehulled, autoclaved, cooked and enzyme supplemented to raw yellow peas on performance of broiler chicks. Pakistan Journal of Nutrition 5:569-572.

Francis, G., H. P. S. Makkar, and K. Becker. 2001. Antinutritional factors present in plant-derived alternate fish feed ingredients and their effects in fish. Aquaculture 199:197-227.

Furukawa, A., and H. Tsukahara. 1966. On the acid method for determination of chromic oxide as an index substance in the study of digestibility of fish feed. Bull. Jpn. Sot. Sci. Fish 32:502-506.

Glencross, B. D., T. Boujard, and S. J. Kaushik. 2003. Influence of oligosaccharides on the digestibility of lupin meals when fed to rainbow trout, Oncorhynchus mykiss. Aquaculture 219:703-713.

Gomes, E. F., G. Corraze, and S. Kaushik. 1993. Effects of dietary incorporation of a co-extruded plant protein (rapeseed and peas) on growth, nutrient utilization and muscle fatty acid composition of rainbow trout (Oncorhynchus mykiss). Aquaculture 113:339-353.

Gouveia, A., and S. J. Davies. 2000. Inclusion of an extruded dehulled pea seed meal in diets for juvenile European sea bass (Dicentrarchus labrax). Aquaculture 182:183-193.

Gouveia, A., and S. J. Davies. 2000. Inclusion of an extruded dehulled pea seed meal in diets for juvenile European sea bass (Dicentrarchus labrax). Aquaculture 182:183-193.

Johnston, R. A., J. S. Quick, and B. J. Donnelly. 1980. Note on comparison of pigment extraction and reflectance colorimeter methods for evaluation semolina color. Cereal Chem. 57:447-448 [Online.].

NRC (National Research Council). 1993. Nutrient Requirements of fish. National Academy Press, Washington, DC.

Park, H., R. A. Flores, and L. A. Johnson. 1997. Preparation of Fish Feed Ingredients: Reduction of Carotenoids in Corn Gluten Meal. J. Agric. Food Chem. 45:2088-2092.

Periago, M., H. Englyst, and G. Hudson. 1996. The Influence of Thermal Processing on the Nonstarch Polysaccharide (NSP) Content andin Vitro Digestibility of Starch in Peas (Pisum sativum L.). Lebensmittel-Wissenschaft und-Technologie 29:33-40.

Sokal, R., and F. Rohlf. 1969. Biometría. Principios y métodos estadísticos en la investigación biológica. Ediciones H, Spain.

Stein, H. H., and R.A. Bohlke. 2007. The effects of thermal treatment of field peas (Pisum sativum L.) on nutrient and energy digestibility by growing pigs. J. Anim. Sci. 85:1424-1431.

Thiessen, D., G. Campbell, and P. Adelizi. 2003. Digestibility and growth performance of juvenile rainbow trout (Oncorhynchus mykiss) fed with pea and canola. Aquaculture Nutrition 9:67-75.

Trugo, L. C., C. M. Donangelo, N. M. F. Trugo, and K. E. Bach Knudsen. 2000. Effect of Heat Treatment on Nutritional Quality of Germinated Legume Seeds. J. Agric. Food Chem. 48:20822086.

Vandenberg, G., and J. De la Noüe. 2001. Apparent digestibility comparison in rainbow trout $(\mathrm{On}$ corhynchus mykiss) assessed using three methods of faeces collection and thee digestibility markers. Aquaculture Nutrition 7:237-245.

Vidal-Valverde, C., J. Frias, A. Hernández, P. J. Martín-Alvarez, I. Sierra, C. Rodríguez, I. Blazquez, and G. Vicente. 2003. Assessment of nutritional compounds and antinutritional factors in pea (Pisum sativum) seeds. J. Sci. Food Agric. 83:298-306.

Wang, Y., K. Li, H. Han, Z. X. Zheng, and D. P. Bureau. 2008. Potential of using a blend of rendered animal protein ingredients to replace fish meal in practical diets for malabar grouper (Epinephelus malabricus). Aquaculture 281:113-117. 